\title{
Adapted hydropower-driven water supply system: assessment of an underground application in an Indonesian karst area
}

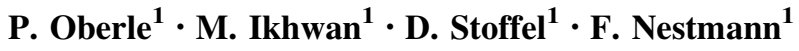

Received: 15 December 2015/Accepted: 11 May 2016/Published online: 1 June 2016

(c) The Author(s) 2016. This article is published with open access at Springerlink.com

\begin{abstract}
Populated karst landscapes can be found all over the world, although their natural boundary conditions mostly lead to distinct challenges regarding a sustainable water supply. Especially in developing and emerging countries, this situation aggravates since appropriate technologies and water management concepts are rarely available. Against this background, the interdisciplinary, German-Indonesian joint project "Integrated Water Resources Management (IWRM) Indonesia", funded by the German Federal Ministry of Education and Research (BMBF), focused on the development and exemplary implementation of adapted techniques to remedy the partly severe water scarcity in the region Gunung Sewu. This karst area, widely known as "Java's poorhouse", is located on the southern coast of Java Island and distinctly suffers from the mentioned constraints. Under the aegis of the Karlsruhe Institute of Technology (KIT), the conceptual and technical achievements of the "IWRM Indonesia" joint research project are characterized by a high potential for multiplication not only for karst areas but also for nonkarst regions. One of the project's major accomplishments is the erection of an innovative hydropower-driven water supply facility located in a karst cave $100 \mathrm{~m}$ below ground and continuously supplying tens of thousands of people with fresh water. Referring to the plant's innovative character and the demanding conditions on-site, the implementation was a highly iterative process leading to today's autonomous operation by an Indonesian public authority.
\end{abstract}

P. Oberle

peter.oberle@kit.edu

1 Institute for Water and River Basin Management (IWG), Karlsruhe Institute for Technology (KIT), Kaiserstrasse 12, 76131 Karlsruhe, Germany
Based on the experiences gained during design, construction, operation and monitoring phase, this paper introduces an implementation approach for adapted technologies as well as a comprising technical and economical assessment of the plant's operation.

Keywords Water supply · Hydropower - Pump as turbine . Adapted technology $\cdot$ Capacity development

\section{Introduction}

One target of the United Nations' Millennium Development Goals adopted in the year 2000 is to halve, by 2015 , the proportion of the population without sustainable access to safe drinking water. In 2010, this goal was achieved through providing durable access to a source of drinking water for more than 2 billion people. However, there are still more than 780 million people around the world suffering from water shortage. According to the United Nations reasons for the occurrence of water scarcity in many places are i.a. difficult-to-access water resources, deficient water infrastructure as well as a steady growth of water consumption (UNICEF and WHO 2012).

Especially the limited accessibility of water resources is a typical persistent problem appearing in karst areas, which cover approx. $20 \%$ of the earth's surface (see Fig. 1); more than $25 \%$ of the world's population depend on karst aquifers for fresh water supply (Ford and Williams 2007). Due to the karstified underground with high infiltration rates and lacking storage possibilities at the surface, karst areas are very often characterized by severe water shortage. These circumstances have been comprehensively investigated and reported for numerous karst regions all over the world (e.g., Wang et al. 2004; Nguyen et al. 2013). 
Fig. 1 Global distribution of carbonate rocks (Williams and Ford 2006)

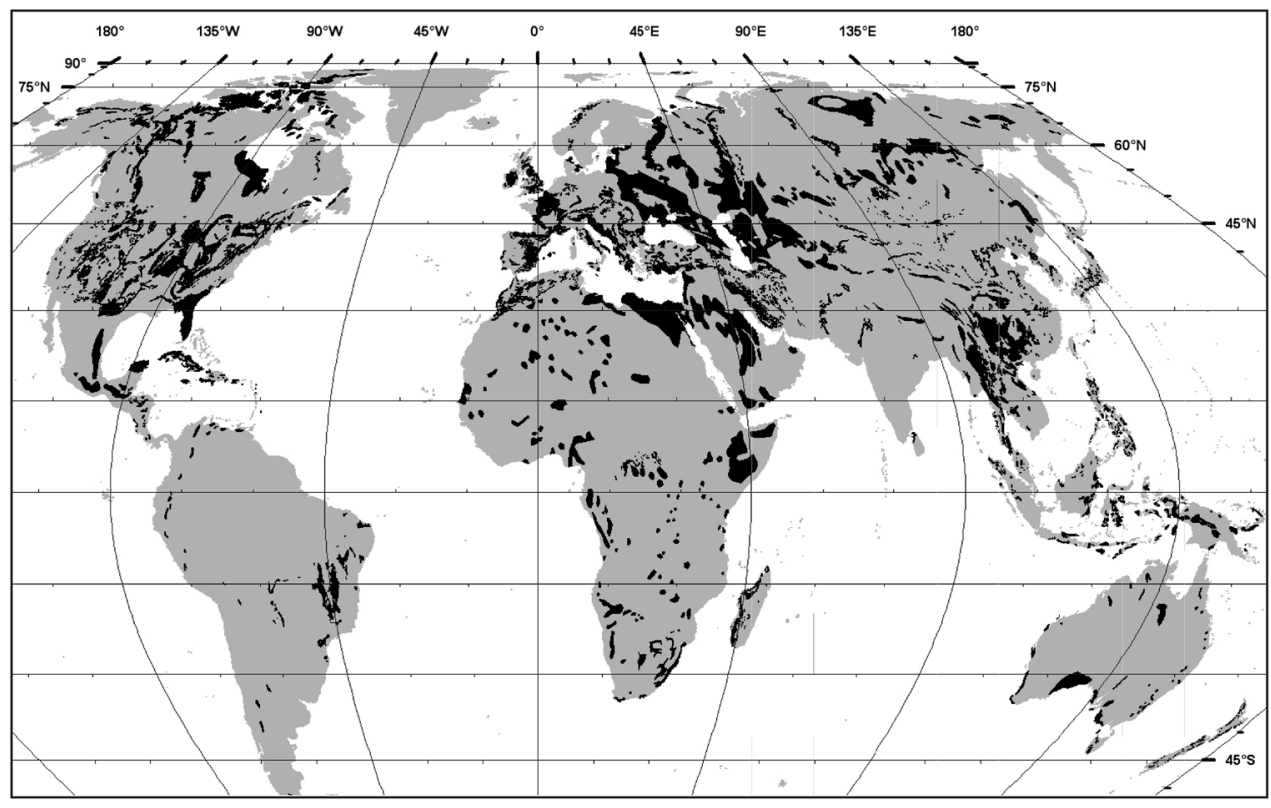

Fig. 2 Hydrogeological scheme showing the main elements of a karst aquifer (adapted from Goldscheider and Drew 2007)

At the same time mostly there are underground water resources available throughout the whole year (see Fig. 2) which could be used to enhance the local water supply in the affected areas. However, due to their irregular spatial and temporal distribution exploration and exploitation is challenging and in consequence of the common deep underground location of the aquifer associated with high extraction costs. In addition low filtration capacity of carbonate rock leads to high vulnerability to contamination.

The region Gunung Sewu, located in the district of Gunung Kidul, Yogyakarta Special Region (DIY), Indonesia, is geologically dominated by karstified reef limestone formations (see Fig. 3). The Indonesian government has made a lot of effort during the past decades to improve the living conditions of the region's population by enhancement of the local water supply. However, a sustainable solution has not been established yet, whereby the region is still afflicted with partly severe water scarcity problems especially during the dry season from May to October. During these times, many households had to live with less than $10 \mathrm{~L}$ per capita per day (lcpd) leading to an enduring hindrance of the region's development (Scholz et al. 2004). In consequence, many inhabitants were forced to leave their homes since mid of the twentieth century, leading to a lack of human capital commonly known as "brain drain effect" (Nibbering 1991). So the water 

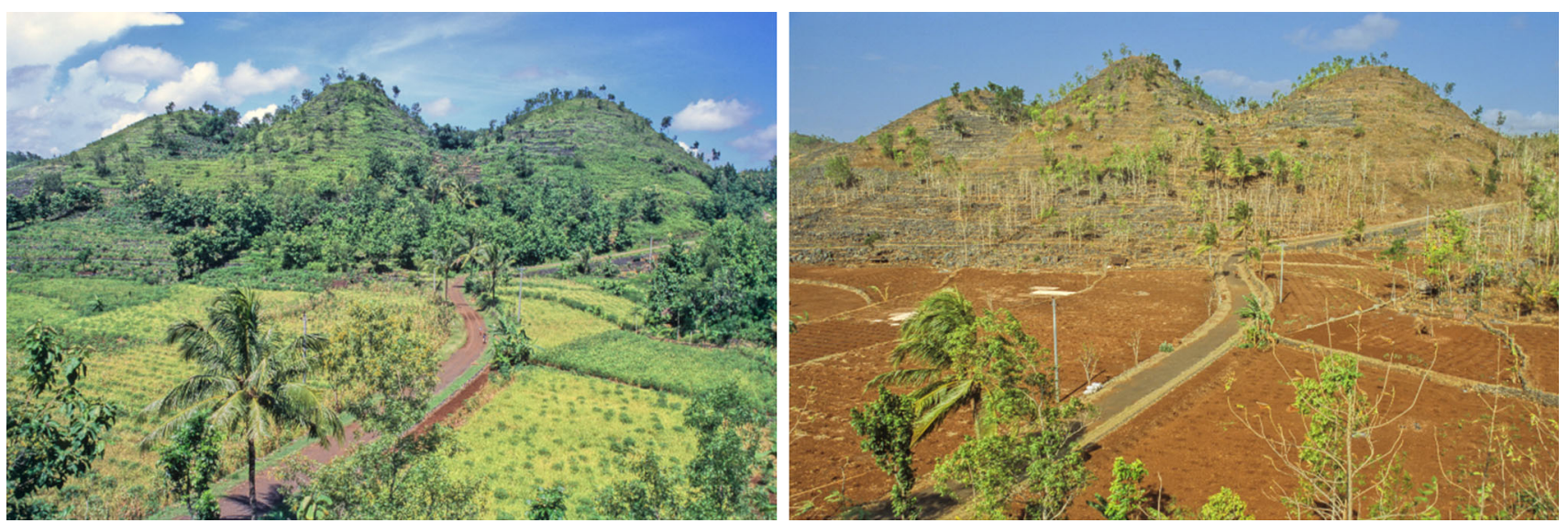

Fig. 3 Karst hill landscape of Gunung Sewu during rainy (left) and dry season (right) (Scholz et al. 2004, private collection)

shortage persistently retarded the area's development wherefore Gunung Sewu is listed since 2005 as one of Indonesia's most disadvantaged regions by the Indonesian government (KEMENNEG PDT 2005).

In this context, explorations by a British consultant under the assignment of the Indonesian Ministry of Public Works (PU) were accomplished in the 1980s to assess Gunung Sewu's underground water resources and potential sites for their utilization (MacDonald and Partners 1984). Essentially these studies revealed the major potential of the karst aquifer and thus lead to its first-time exploitation applying conventional pumping stations (initially by diesel generator-driven pumps, later by grid-supplied pumps). However, the dependency of the water supply from diesel fuel or electricity (in Indonesia mainly generated through fossil energy carriers) restrains the sustainability of these pumping stations from economic and ecologic point of view.

Against this background, a German-Indonesian network focused on the development of adapted technologies and water management strategies to sustainably improve the water supply situation in Gunung Sewu (Nestmann et al. 2010). The frame for these activities was the R\&D-project "Integrated Water Resources Management (IWRM) Indonesia", which was funded by the German Federal Ministry of Education and Research (BMBF). To meet the demands associated with the enhancement of the water supply in a rural and poorly developed tropical karst area, an interdisciplinary approach was favored involving scientific institutions, companies and public authorities from both countries. Under the aegis of the Karlsruhe Institute of Technology (KIT) all essential facets were covered such as exploration of water resources, water extraction, distribution and quality assurance as well as wastewater treatment. The superior goal was the exemplary implementation of the developed technologies and methods in close cooperation with the Indonesian partners, whereby a comprehensive knowledge exchange was accomplished. In total nine pilot plants covering the entire water cycle were implemented within this cooperation, considering the natural (climatic, hydrogeological, hydraulic, etc.) as well as the social boundary conditions.

Here the results of the studies of MacDonald and Partners (1984) also served as initial data basis for the development of two supplementary concepts by KIT regarding a sustainable exploitation of karst water resources (Nestmann et al. 2009). Since various experiences show that largescale and highly sophisticated engineering solutions in karst areas often fail and might cause irreversible environmental impact to the local water regime (e.g., Milanovic 2002), small-scale and decentralized solutions are endorsed which can be adapted to the local conditions.

One of these supply concepts focuses on the erection of an underground water storage with a concrete barrage in a water-bearing karst cave. The barrage closes the cave's entire cross section to dam the continuously flowing water. Hereby, a hydraulic head is created which can be utilized to operate a hydropower-driven pumping system to partially convey the karst water to the surface. This approach's prospects of success mainly depend on the local hydrogeological conditions (see "Elaboration of design parameters") since the karst rock's porosity might hinder longterm water storage at some locations. Based on comprehensive field studies by KIT in close cooperation with local partners the cave Gua Bribin, located in the karst region Gunung Sewu, was chosen to be an appropriate site for the first-time implementation of this concept. Here, in a depth of 100 meters below ground, a hydropowered water extraction plant was erected enabling the continuous supply of 75.000 people with water since 2011 .

The second water supply concept relinquishes the barrage for the benefit of a wooden penstock to gain the required pressure head for the hydropower-driven supply system. Wood as construction material is versatile for this 
application since it is of low weight but durable if permanently saturated and it enables the erection of the penstock also at locations which are hard to access. This concept is particularly suitable for sites showing a steep incline (e.g., a waterfall), whereby the penstock's required length to provide an adequate pressure head remains limited. As a consequence the structural effort and the associated costs might be kept on a comparatively low level. To disseminate the knowledge referring to this concept, a demonstration plant was erected in close cooperation with several departments of the local University Gadjah Mada, Yogyakarta (Nestmann et al. 2015). In the future, this installation serves as research and training facility for students as well as for employees of companies and public authorities working in the field of water and/or energy supply.

This present paper focuses on major challenges and constraints during the development and implementation of the first supply concept in the karst cave Gua Bribin (later referred to as 'Bribin'). Based on these experiences, an iterative implementation process is introduced regarding development, adaption and implementation of water technologies in remote karst and non-karst areas. In addition, both a technical as well as an economic evaluation of Bribin's continuous operation are presented.

\section{Natural boundary conditions of Gunung Sewu}

The district Gunung Kidul, situated in Central Java, is characterized by tropical winter monsoon with a mean annual rain intensity of approx. $2000 \mathrm{~mm}$ which, however, is distributed strongly unequal (see Fig. 4). The spatial disparity refers to increasing mean annual rainfall with proximity to the Indian Ocean as well as with increasing altitude. Since rainfall mainly occurs during the rainy season from November to April with a mean rain frequency of 20 days per month a temporary inequality occurs; during dry season this value decreases to 3 days per month in average.

From geological point of view Gunung Kidul can be divided in the three subterritories Gunung Sewu, Wonosari Plateau and Baturagung massif. The karst area Gunung Sewu is located in the southern, coastal part and covers approx. $60 \%$ of the district's total area of $1400 \mathrm{~km}^{2} . \mathrm{Gu}$ nung Sewu is bounded in the north by the Wonosari Plateau, another geomorphologic unit that consists of soft Miocene oolite limestone. Compared with the karst area's hilly surface, the Wonosari Plateau is plane and on lower altitude. The third big geomorphologic unit in Gunung Kidul is the Baturagung massif in the district's northwestern part. This mountain chain shows the region's highest elevations and consists of volcanic deposits of Eocene to early Miocene age (Waltham et al. 1985).

The name Gunung Sewu, which is the Indonesian expression for "land of thousand hills", refers to the remarkable cone karst formations as shown in Figs. 2 and 5 . The compact reef limestone, which is mainly of Miocene age, has a thickness of several hundred meters. The local karst landscape with its characteristic hills, sinkholes, extensive and often interlinked cave systems resulted from intensive tropical limestone dissolution that has taken place for thousands of years. Due to the strong karstification the Gunung Sewu is marked by lacking surface runoff. Rainwater quickly infiltrates and is further distributed through a widely ramified subsurface drainage system, which finally
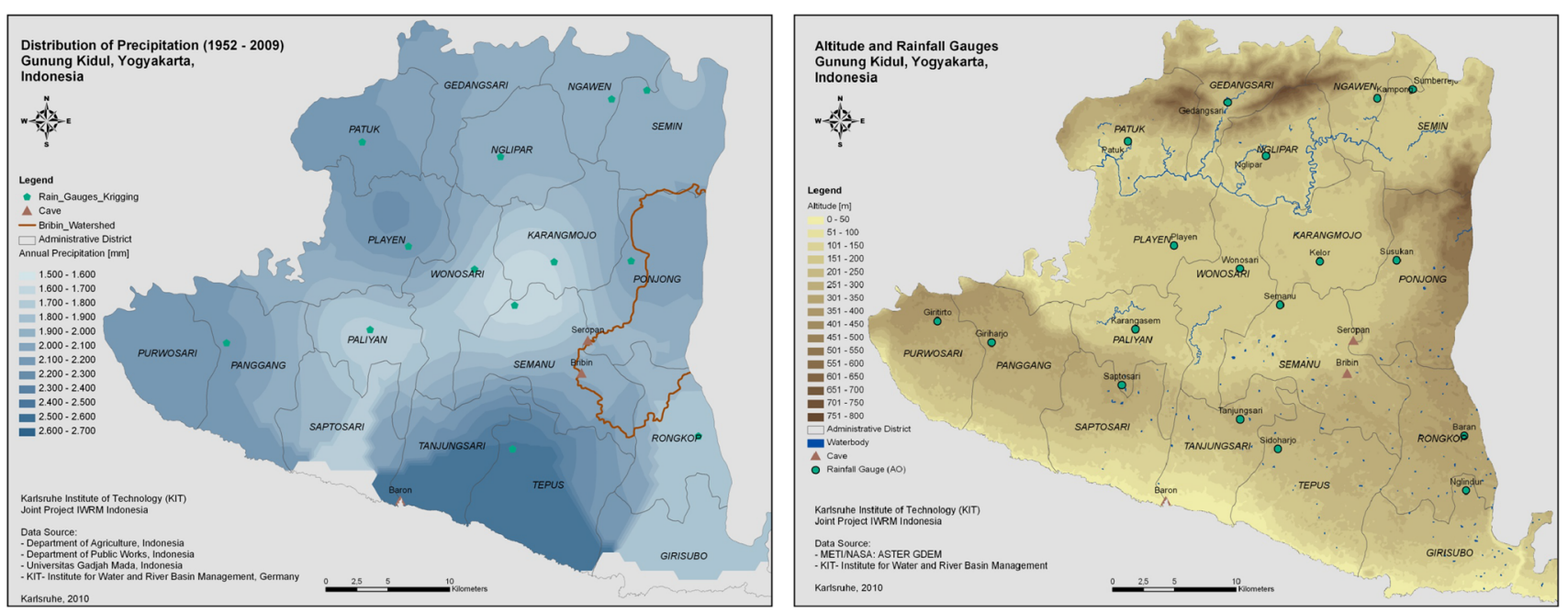

Fig. 4 Precipitation (left) (data source: Department of Agriculture, Indonesia; Department of Public Works, Indonesia; University Gadjah Mada, Indonesia; KIT) and topographical data (right) (data source: METI/NASA: ASTER GDEM; KIT) of Gunung Kidul 

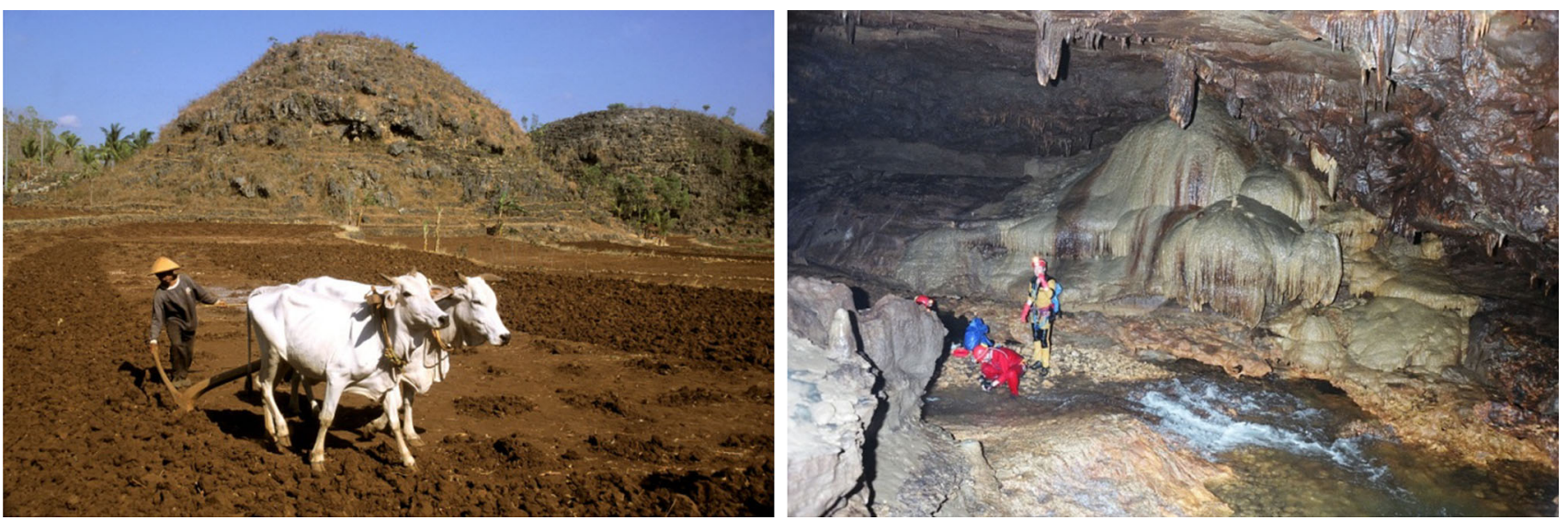

Fig. 5 Agriculture in Gunung Sewu afflicted with water scarcity during dry seasons (left), all-season water-bearing karst caves in the underground (right)

discharges the water through coastal or submarine springs into the Indian Ocean.

Due to the storage resp. retention capacity of the karst aquifer (temporary filling during rainy seasons, successive drainage during dry seasons) many of Gunung Sewu's underground rivers are water-bearing throughout the year. Still, a prediction of a karst river's seasonal discharge distribution is generally very challenging and requires a reliable database, which is commonly not given in such remote areas due to lacking discharge measurements in underground drainage systems. In addition, information about influencing factors to the rivers' flow rate is mostly also not available or incomplete, e.g., referring to the annual precipitation rate, its temporal and spatial fluctuation, geologic information resp. hydrogeological boundary conditions of the karst underground, etc. (Oberle 2011).

The initially very limited and mostly discontinuous data record was one of the main constraints for the implementation of a sustainable water supply system in Gunung Sewu. To overcome this challenge, 2 years of feasibility studies prior to the later implementation had been carried out by KIT to complement the existing data about the cave Gua Bribin as well as about the river's catchment area (see Fig. 6). The associated monitoring had focused i.a. on the river's discharge characteristic as design value for the planned hydropower-driven supply system. Based on topographic and geologic findings a suitable location in Gua Bribin could be identified as potential construction site.

The monitoring activities had been continued beyond the feasibility studies in order to further extend the valid data which served as basis for the water supply system's dimensioning. Here, proof had been found that the dry season's discharge temporarily undercut the assumed minimum discharge by up to $30 \%$. Due to the linear relation between declining discharge and the plant's output capacity further investigations of potential causes for the discharge decrease had been required.

In this regard, rainfall data of the years 1952-2009 were intensively evaluated within the frame of a hydrological study. The results showed that starting in 2002 the unexpected low discharge during the dry season correlated with exceptional low mean annual rainfall (see Fig. 7). The study also concluded that up to now an influence of further impact factors on the discharge such as morphological changes (e.g., caused by karst mining or earthquakes) can be neglected. Subsequently, the correlation between mean annual rainfall and river discharge during the dry season was qualitatively proven by the re-increase of both values in the years 2010 and 2011 to the pre-2002 level (here, the results of KIT's hydrological study was supplemented by further data of 2010 and 2011, see Fig. 7). Accordingly, the river discharge's onset is assumed to be a short-term condition caused by an extraordinary, long-lasting low precipitation period (Nestmann et al. 2012).

The hydrological study also dealt with (trend) analyses of the precipitation's variability influenced by the climate phenomenon "El Niño Southern Oscillation (ENSO)" (Brunsch et al. 2011). Here it was found that the uneven temporary rainfall distribution between the rainy and dry season aggravates during years afflicted by the El-Niño phenomenon, which occurred 11 times during the investigated time-span. The afflicted years showed a decrease of the mean annual rain intensity up to $65 \%$.

\section{Water supply situation in Gunung Sewu}

According to Lux (2004) the governmental attempts to improve the water supply in Gunung Sewu can be divided into three phases. In the first phase starting around 1970, the governmental scheme focused on the utilization of so- 

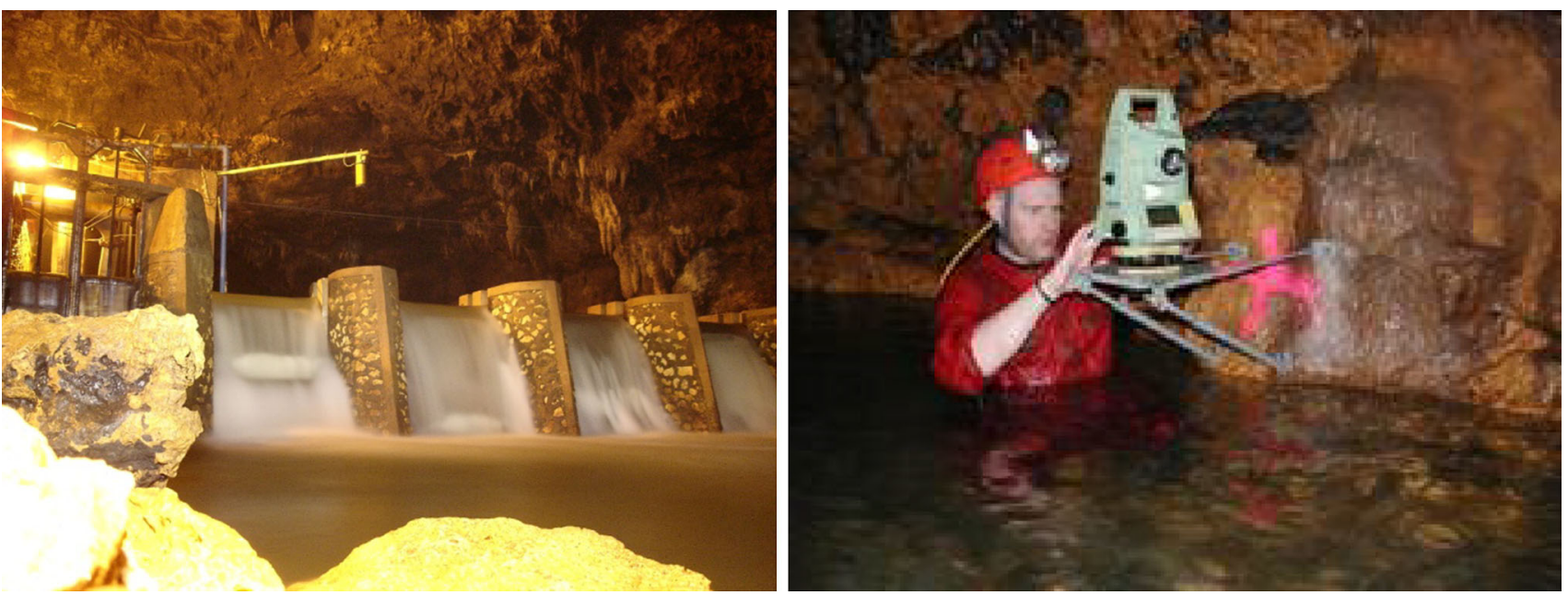

Fig. 6 Continuous discharge monitoring using a radar sensor for contact-free water level measurement (left), mapping of the cave using lasertachymetry (right)

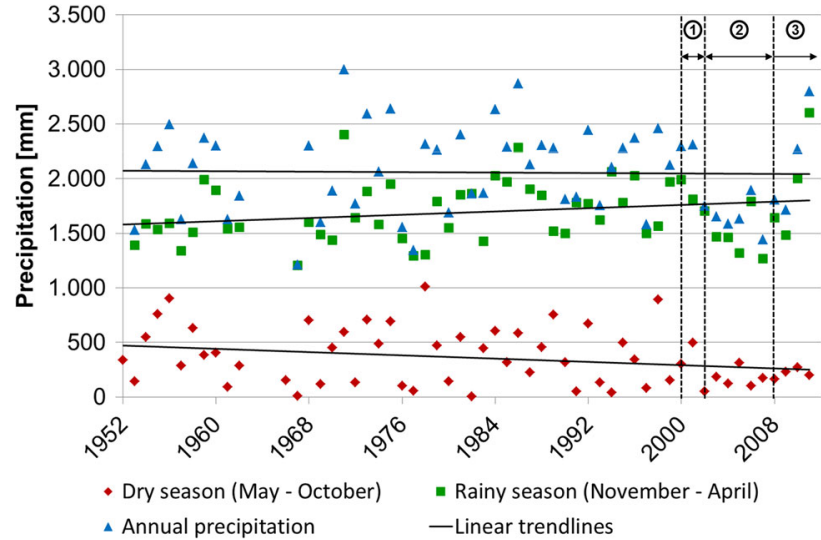

Fig. 7 Annual precipitation in Gunung Kidul in the years 1952-2011; the figure comprises mean values of 13 rainfall gauges distributed over the entire district (data source: Department of Agriculture, Indonesia; KIT). The marked timespans refer to (1) the feasibility study, (2) the plant's construction and to (3) the operation phase

called "Telagas" ("water catch", see Fig. 8). These basins are natural water accumulations occurring in lower valleys with impermeable clay soil. These resources were intended to be used to supply the neighboring settlements during times of low precipitation. This approach was and is used by the locals, however, it is afflicted with distinct disadvantages due to the lack of suitable sites, common failures like a complete drying up during the dry season or drainage of the water through sinkholes into the underlying limestone (Waltham et al. 1985). Additionally, the water quality of Telagas is commonly impaired, e.g., by algae growth caused by long-term insolation.

In the 1980s, the second phase began introducing alternatives for water supply within the frame of a
UNICEF-supported development project. One alternative concentrated on a water harvesting concept applying private built cisterns. However, during the six-month dry season only a provision of approx. $10 \mathrm{~L}$ per capita per day (lpcd) was feasible for an average household of 4 people due to the cisterns' common dimensions of approx. $9 \mathrm{~m}^{3}$. This supply was not sufficient to cover the daily minimum water supply of $50 \mathrm{lpcd}$ which is defined by UNESCO/ Division of Water Sciences (2003) to secure people's livelihood and to enable an initial development of the area concerned. Additionally, with higher consumption the supply by cisterns commonly did not last for the entire dry period. The situation by that time stimulated the establishment of private water truck businesses to deliver clean water to Gunung Sewu. However, this solution was only feasible for households who could afford the transport costs (Dittmann et al. 2011).

Another alternative was introduced in the late of the 1980s and focused on the utilization of the sub-surface karst water resources. Also supported by UNICEF small dams were erected in several underground karst caves to feed diesel generator-driven pumping systems. The main constraints of this water supply concept are the distinct operational costs related to the provision of energy for the high-pressure pumps (see "Economical assessment and comparison to alternative supply concepts"), wherefore the sustainability was constrained. In addition, the operation of diesel generators had a negative ecological impact on the local environment due to pollutant emissions and contamination of the karst aquifer by fuel leakages.

The third phase starting mid of the 1990s where, despite the lacking sustainability of the conventional water extraction concepts, the Indonesian government started to massively implement water distribution pipelines covering 



Fig. 8 Manual utilization of a water catch's soiled water (left), "Telaga" dried-out during dry season (right)

a large share of Gunung Sewu's area. Unfortunately, the central issue regarding the lacking water quantity was not solved by that time. Therefore, the newly installed pipelines did not continuously convey water; some even were never used since the system's commissioning.

Against this background one of the major outcomes of the IWRM Indonesia is the project's contribution to the establishment of a fourth stage regarding the development of a sustainable water supply for Gunung Sewu (see Fig. 9). This stage is valid to this date (status October 2015) and comprises the erection of the ecologically compatible and highly adapted, hydropower-driven water supply facility Bribin, associated by the rehabilitation and optimization of the water distribution network. The plant's functionality and the experiences gained during its construction and operation will be discussed in the following chapters.

Additionally, the fourth development stage comprised again the erection of private built cisterns, which in this case could be used for rainfall harvesting during rainy season as well as to store the water supplied from Bribin especially during dry season. Accordingly, both concepts complement each other to enhance the local all-season water supply. In this context Breiner and Müller (2015) focused on development and transfer of adapted concepts and concrete formula (based on locally available materials) to optimize the construction of those cisterns.

\section{Hydropower-driven water supply}

\section{Operating principal}

In general, sustainable water pumping requires a reliable energy supply in order to realize the intended flow rates to a higher altitude. If the related operational costs can be kept at a manageable level strongly depends on the applied energy supply approach.

In karst areas groundwater resources are often located deep underground. Considering further on a lacking infrastructure, e.g., in remote areas, isolated applications which are operated independently from external energy sources can be advantageous (see "Economical assessment and comparison to alternative supply concepts"). Gunung Sewu for instance is not entirely electrified, so grid-driven pumps cannot be applied at random sites. Pump stations driven by diesel generators, however, are afflicted with the emergence of emissions as well as with distinct operational costs. Accordingly, Bribin's supply system was intended to be driven by regenerative energy to ensure the facility's sustainable operation from technical and economic point of view. Based on comprehensive field studies and pre-investigations the implementation of a hydropower drive was assumed to be feasible utilizing the existing hydropower potential by damming Bribin River with a concrete
Fig. 9 Development towards sustainable a water supply in Gunung Sewu (modified from Dittmann et al. 2011)

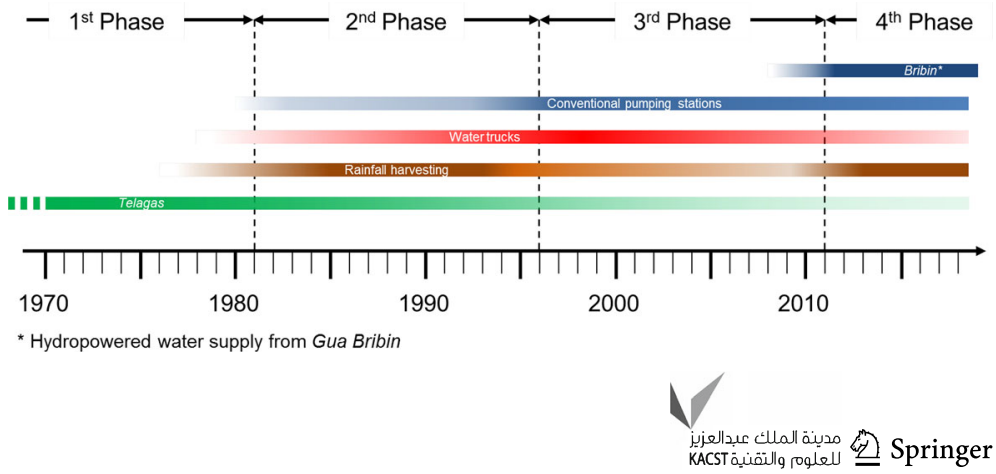


Fig. 10 Main design values for the hydropower-based supply systems (modified from Nestmann et al. 2009)

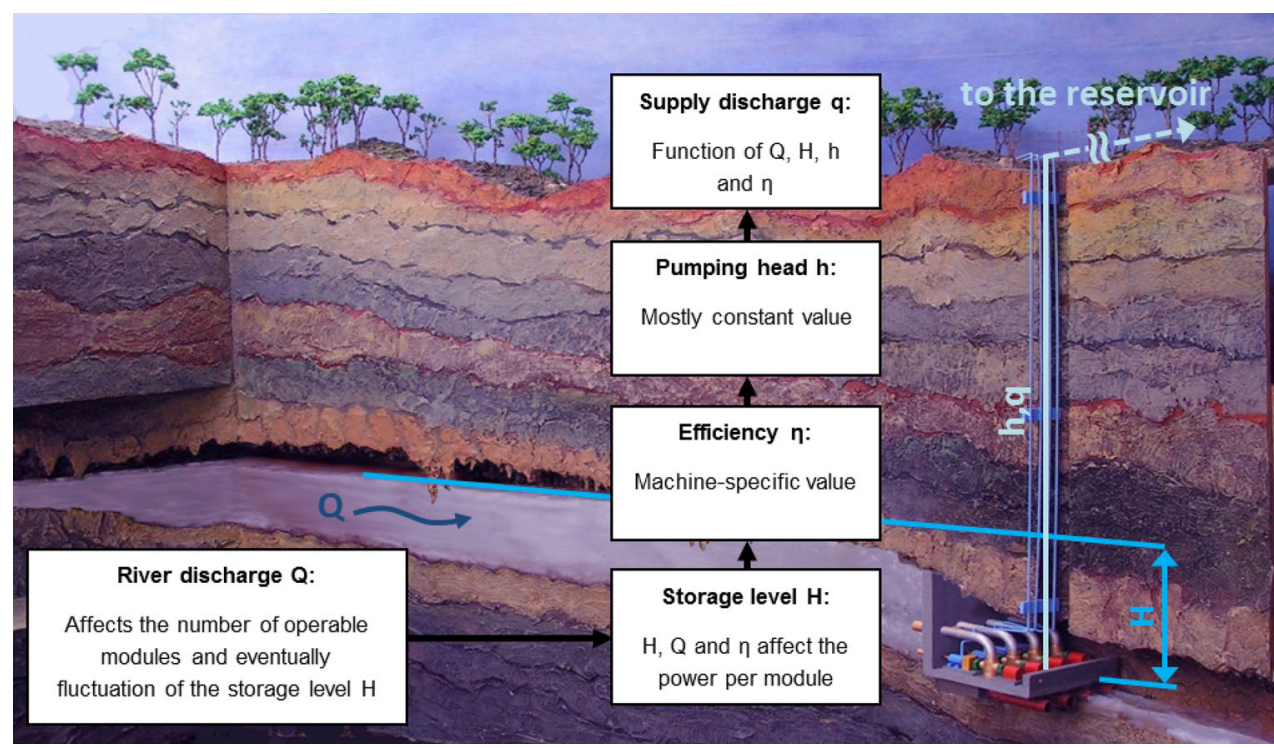

barrage. The supply facility itself (see Fig. 10) is located on a concrete machinery platform $100 \mathrm{~m}$ below ground and can be accessed by a vertical shaft (a brief description of the plant's construction can be found in "Implementation process").

To utilize the hydropower potential reverse driven centrifugal pumps ("pumps as turbines", PAT) are applied instead of common turbines (see "Machine selection"). Pumps used as turbines represent a technology, which excels through high availability of applicable machinery associated with low investment costs, low-maintenance effort as well as with high operating efficiencies at nominal conditions. The pumps in reverse mode are mechanically linked to high-pressure feed pumps which supply the river water partially to an elevated distribution reservoir. This setup of direct coupled machines (further on referred to as 'conveying module' or 'module') can be characterized through low complexity and thus through high robustness.

The efficient operation of a PAT-based water supply system can be achieved by proper machine selection with due regard to the local conditions, whereby five major rating parameters have to be considered in particular: Design discharge $Q$ (associated with an evaluation of minimum and maximum discharge), storage level resp. hydraulic head $H$, pumping head $h$, machine efficiency $\eta$ and supply discharge $\mathrm{q}$.

\section{Elaboration of design parameters}

\section{Discharge monitoring}

As described in "Natural boundary conditions of Gunung Sewu" the prediction of a karst river's discharge variability is very demanding especially in (sub-) tropical regions.
This is due to the generally inhomogeneous structure and high permeability of karst combined with the extreme fluctuation of precipitation.

For development of an appropriate design of a hydropower-driven water supply system as implemented in Bribin, the determination of the turbines (size and quantity) and thus of the design discharge $\mathrm{Q}_{\mathrm{D}}$ is crucial since together with the pressure head $\mathrm{H}$ and the machines' efficiency $\eta$ it determines the producible power at a certain site (see Fig. 10). In this regard, a long-term monitoring of a karst river's discharge is of great importance to define the design discharge as well as to specify the assumed minimum and maximum discharge. The minimum discharge $\mathrm{Q}_{\min }$ has to be considered in order to avoid downtimes of the machinery as far as possible. The maximum flood discharge $\mathrm{Q}_{\max }$ has to be known to ensure the plant's all-time safety by proper dimensioning of a flood relief system, which has to be activated in case the river's discharge exceeds the supply system's design value. Defining the total number of modules for utilization of the design discharge should be a compromise between enabling a flexible operation and limiting the system's complexity. This is due to the influence of both aspects on the operational requirements as well as on the costs related to the system's implementation, operation and maintenance.

After critical analyses of the sparse data which was locally available at the beginning of the R\&D activities (sporadic point measurements within 20 years) and reconciliation with own observations (3 years of continuous discharge monitoring, interpretation of hydro-morphological characteristics) it was assumed, that the annual minimum discharge does not deceed $1 \mathrm{~m}^{3} / \mathrm{s}$. Also based on this research peak discharges during the rainy season were expected not to pass values of $6 \mathrm{~m}^{3} / \mathrm{s}$. In accordance with 
all findings, the design discharge of the water supply system was defined to $2 \mathrm{~m}^{3} / \mathrm{s}$.

Considering the hydrological boundary conditions the flood relief system's capacity was set to approx. $9 \mathrm{~m}^{3} / \mathrm{s}$. This value includes safety margins and refers to the plant's design storage level of $15 \mathrm{~m}$ which was defined in accordance to local geological characteristics (see "Determination of the hydraulic head"). As it later became apparent (rainy season 2011/2012), however, peak discharge values distinctly above $10 \mathrm{~m}^{3} / \mathrm{s}$ occurred as well as ongoing high discharge values exceeding the flood relief system's capacity for days. In total this lead to extreme storage levels, which are especially critical in terms of seepage in spatial proximity to the barrage (see "Initial operational phase"). Fortunately they did not cause any damage to the plant or the surrounding geology. Although fragmentary discharge data of the past decades do not allow a statistical classification of this event, investigations of KIT showed the necessity of extending the flood relief system's discharge capacity. Even though it is assumed that the observed event will only occur sporadically in the future, the flood relief system's discharge capacity was extended to approx. $11.5 \mathrm{~m}^{3} / \mathrm{s}$ (also referring to the plant's design storage level of $15 \mathrm{~m}$ ).

\section{Determination of the hydraulic head}

Based on intensive investigations Gua Bribin was found to be suitable for natural or anthropogenic water storage due to its geological and mineralogical features. This can be explained through four major characteristics. Firstly, the cave's section that was chosen for water storage (concerning regular operation) does not show any obvious lateral junctions. Secondly, based on point-by-point analyses the limestone can be characterized as a comparatively compact ridge limestone with a low porosity. The barragesurrounding rock formations were examined in particular, since in this area the maximum pressure gradient occurs during water storage. Here it was found that the pores are mostly not connected so the rock's permeability can be considered as low. If cracks and fissures are present they are either filled with a clay rich limestone (marl) or with in situ precipitated calcite. Thirdly, there is a manganeserich crust on the cave's walls and ceiling (thickness of centimeters to decimeters) which could only emerge through a complete filling of the cave for centuries. Fourthly, in this context sealing effects at the cave's walls were observed which among others lead to the tightness of the small dam that was built by the Indonesian government in the 1980s (see "Water supply situation in Gunung Sewu") (Neumann et al. 2009).

In addition to these findings, comprehensive tracer studies (see Fig. 11) and water balance investigations had been conducted, which also showed no significant water losses along the drainage network's known length of approx. $17 \mathrm{~km}$. However, it was decided that the water storage should only concern the cave's accessible and wellinvestigated section (which is limited on both ends by siphons). Based on these preconditions, a suitable site for the facility's construction was selected enabling a design pressure head $\mathrm{H}$ of $15 \mathrm{~m}$ which was chosen with respect to the karst rock's unknown water holding capacity during long-term operation of the plant (Oberle and Nestmann 2006).

\section{System design and operational aspects}

For the machine selection besides the assumed river discharge and the attainable hydraulic head, the pumping head has to be considered as well. This value mainly refers to the height difference between potential locations for the supply facility and the elevated distribution reservoir. In case of Bribin the distribution reservoir is located on the highest elevation of the surrounding chain of karst hills, which is elevated by $220 \mathrm{~m}$ in relation to the machinery platform (Fig. 12). From there the water is further supplied to the end-users mainly by the impact of gravity.

Considering all mentioned parameters, proper machinery can be selected whose constructional size and resulting inner hydraulic losses determine the attainable efficiency $\eta$. In accordance the supply discharge $q$ results from water availability, the plant's degree of utilization as well as from the supply system's efficiency. To increase the mean supply rate as far as possible through effective utilization of the water yield a modular plant design was chosen as described in the following chapter. Thus, the plant's partial operation is enabled even while distinctly deceeding the above stated minimum river discharge of $1 \mathrm{~m}^{3} / \mathrm{s}$.

\section{Machine selection}

According to "Operating principal" PAT-based water supply can be a suitable technical solution for applications in emerging and developing countries with due regard to the here required limitation of the related technical and financial effort. This effort is mainly determined by the machines' resp. the supply system's complexity, which further on influences the development and implementation process as well as the system's long-term operation and maintenance. Here, the absence of an adjustment device, which on the one hand limits the operating range of a PAT, can be advantageous since on the other hand it leads to a simple, robust and easy-to-maintain machine design compared to conventional turbines. In addition, a PAT can reach a nominal efficiency almost as high as common turbines if the machine is chosen properly in regard of the 



Fig. 11 Installation of pressure sensors for automated water level resp. discharge monitoring in a karst cave (left), manual discharge measurement for data validation (middle), multi-tracer-test with fluorescence dyes (right)
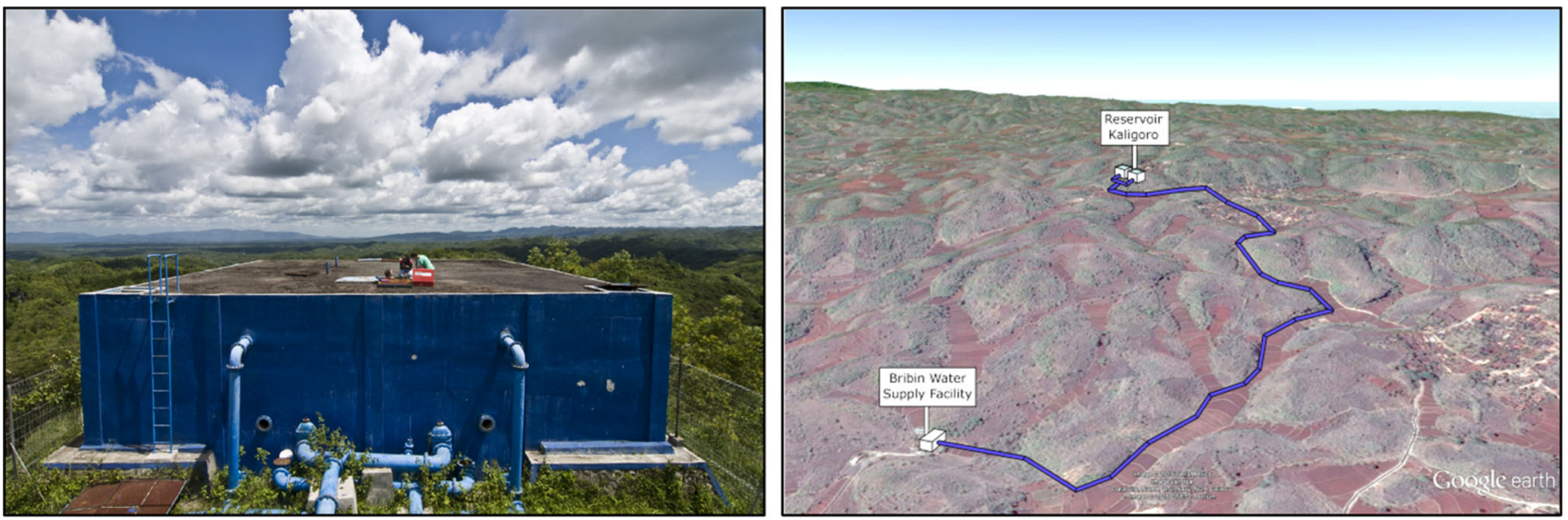

Fig. 12 Reservoir Kaligoro located on the highest elevation of the surrounding chain of karst hills (left), transmission line between Bribin and reservoir Kaligoro with a length of approx. $2.5 \mathrm{~km}$ (right)

local conditions. So the handicap of a PAT's lacking adjustability to discharge variations can be handled by a parallel setup which enables an independent operation of single machines. Therefore a broad discharge range can be covered achieving high efficiencies since the single machines are mostly operated at their nominal point (Oberle et al. 2009).

The selection and adaption resp. optimization of proper machinery was conducted in close cooperation of KIT with the German pump manufacturer KSB AG. For the PAT application a single-stage, single-flow centrifugal pump type Etanorm-R 300-340 was chosen; as high-pressure feed pump a 9-stage, single-flow machine type Multitec D 65/9 6.1 was selected. Since the nominal speeds of both machines distinctly differ (PAT: $1200 \mathrm{~min}^{-1}$; pump: $2200 \mathrm{~min}^{-1}$ ) a gearbox was interposed so both machines can be operated at their respective nominal point leading to an overcompensation of the spur gear's energetic losses. This unit of PAT, gearbox and feed pump, which was implemented in Bribin for the very first time, is further on termed conveying module resp. module. In total Bribin comprises five modules which are set up in parallel to utilize a discharge range from 400 to $2000 \mathrm{l} / \mathrm{s}$.

In case of exceeding the plant's design discharge the inflow to the storage can temporarily not be solely managed by the water supply system. Then an additional release is conducted through a flood relief system consisting of two pipes below the machinery platform and one bypass at a PAT pressure pipe (see Fig. 13 and 14). These three pipes are individually equipped with valves and are to be activated at different storage levels to regulate the plant's discharge capacity in accordance to the respective river discharge and thus to control the hydraulic head within a permitted range. Generally, the system's nominal operation point refers to a hydraulic head of $15 \mathrm{~m}$. To provide a sufficient amount of energy for the feed pumps' operation a minimum head of $10 \mathrm{~m}$ is required. Since the machines' rotation speed correlates with the hydraulic head the system has to be turned off beyond a head of $17 \mathrm{~m}$ to prevent speed-related damages.

Referring to nominal conditions a PAT efficiency of $81 \%$ was achieved based on comprehensive optimization 
Fig. 13 Modular layout of the hydropower-driven water supply system (left), module setup at the test rig of the German pump manufacturer KSB AG (right)

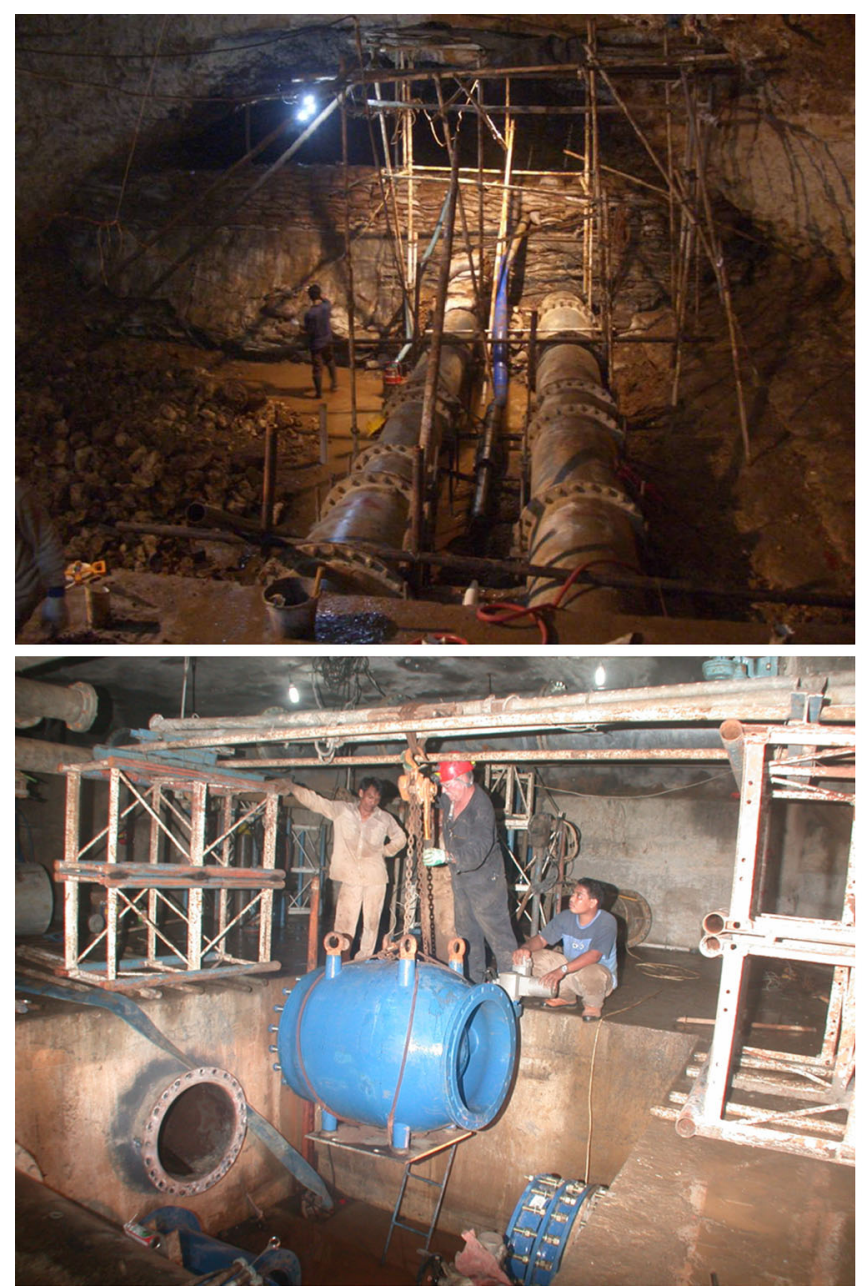

Fig. 14 Impressions of Bribin's construction phase

studies (Singh 2005). Considering also the efficiencies of gearbox (95\%) and feed pump (71\%) the system's total efficiency results to $55 \%$.

Accordingly, a single feed pump is empowered to deliver up to $13 \mathrm{l} / \mathrm{s}$ to the distribution reservoir. At the plant's full
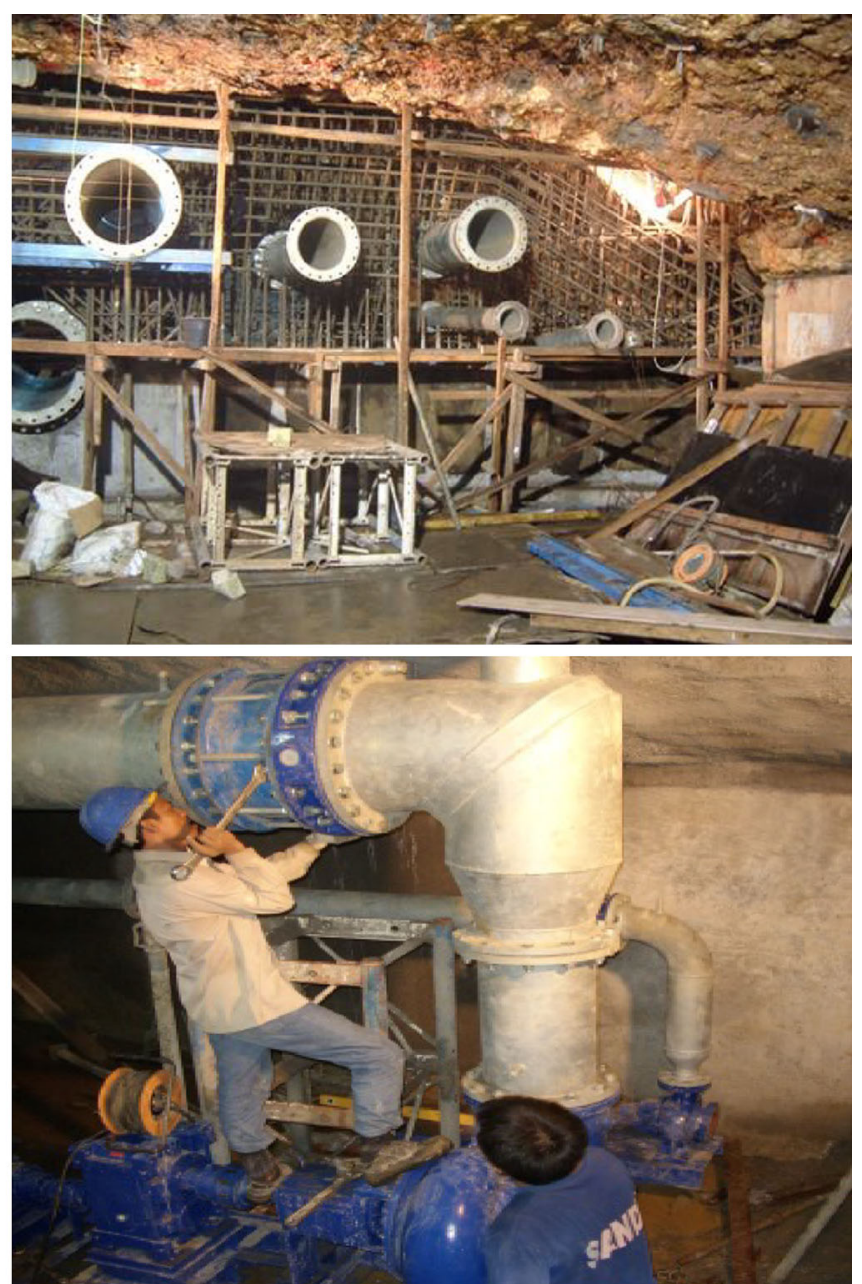

capacity in total approx. $62 \mathrm{l} / \mathrm{s}$ can be supplied. Due to the fact that cost intensive external energy (diesel fuel or electrical energy) is not needed, this facility can cost-efficiently be operated 24/7 (see "Economical assessment and comparison to alternative supply concepts"). 


\section{Implementation process}

\section{Construction of the underground supply facility Bribin}

During the initial project phase, it was agreed that the German side was responsible for provision of an appropriate technical plant design, the machinery and the plant's control system. Here, industry partners such as KSB AG (pump manufacturer) and Walcher GmbH \& Co. KG (developer of control and energy management systems) were involved in the development process. The Indonesian side was in charge for the subsequent execution of the construction works, which were carried out by local construction companies and plant manufacturers. These works, which are briefly described as follows, had mainly to be conducted during dry season resp. during times of low discharge.

According to Nestmann et al. (2009) the construction phase was started in 2004 with the drilling of the vertical shaft (using an innovative vertical drilling machine of the German industry partner Herrenknecht AG) for insertion of building material as well as for the plant's future operation and maintenance. Subsequently the installation of the flood relief lines (leading the inflowing water during the construction phase), mining activities for widening the cavern in the area of the rock abutment as well as further preparing measures for the construction of the machinery platform were carried out.

In 2006 a disastrous 6.3-magnitude (Richter scale) earthquake occurred, whose epicenter was located $30 \mathrm{~km}$ south-east of Yogyakarta city. The construction site facilities were mostly intact, however, the water level on-site raised approx. $2 \mathrm{~m}$ after the earthquake, wherefore the works' continuation was impossible. Supported by German professional divers it was found that the water level increase referred to an earthquake-induced rockfall downstream of the construction site. In total approx. $1000 \mathrm{~m}^{3}$ of rocks blocked the river bed, which had to be removed applying blasting activities by German and Indonesian specialists. Finally a reduction of the backwater effect was achieved and the construction works were resumed with the implementation of the concrete barrage. Due to the working conditions underground (narrowness, high humidity, high temperature, etc.) the concrete works were very challenging. Thus it was decided to realize the monolithic barrage from base to top in six sections, each implemented in intervals of several days using a total of approx. $220 \mathrm{~m}^{3}$ of concrete. The concrete works were completed with the finalization of the contact injections between barrage and rock applying specifically developed materials.

Subsequently a first conveying module and two controlling valves (latter are main components of the flood relief pipes below the platform) were implemented. So in August 2008 the first test storage was accomplished under great public attention with a discharge of approx. $1.2 \mathrm{~m}^{3} / \mathrm{s}$. Based on the assumed saturation of the surrounding rock during the storage phase and considering a residual risk of water losses through undiscovered gaps in the karst rock, a duration of at least 1-2 weeks was assumed to reach the design storage level of $15 \mathrm{~m}$. However, within less than 2 days, this level was even exceeded.

Based on comprehensive monitoring activities carried out during the successful test storage the accomplishment of injection measures (see "Assessment of the injection measures"), the extension of the supply system to a total of five modules (see "Machine selection") as well as the implementation of the electronic control system (see "Manual vs. full automated operation") were decided.

\section{General implementation process}

As experienced within the entire implementation process, the sustainable improvement of a deficient water supply situation in remote areas with poor infrastructure is mainly depending on two key aspects: (1) A reliable data base concerning the decisive boundary conditions (in particular concerning demand situation, hydrogeology, geography, socio-economics, socio-culture) as foundation for adjusting (2) highly adaptable technologies to remedy the prevalent condition. However, especially the boundary conditions in emerging and developing countries challenge the development and implementation process distinctly. Here a technology transfer cannot be considered as straight-forward process but as iterative procedure which includes the four key steps development, innovation, implementation and optimization as shown in Fig. 15.

This figure illustrates the technology transfer process which evolved during designing, implementation and operation of the underground water supply facility Bribin. The included challenges and key elements are considered as the main determining factors to the entire implementation process. An integral key element, which stands out among the others, is the "capacity development" (CD), which includes a comprehensive and adapted technology and knowledge transfer for the concerned stakeholders and thus ensures the sustainability of the implementation activities.

In general, the CD measures within the IWRM joint project were carried out as a multilevel approach according to the concepts described by van Hofwegen (2004) and Alaerts (2009). Therefore, the technology and knowledge transfer for the long-term operation and autonomous maintenance of Bribin covered both the institutional and individual level. The activities involving the institutional level included, among others, the 
Fig. 15 Iterative processes for implementation of innovative technologies



definition of appropriate organizational structures, the elaboration of a business plan for the plant's continuous operation as well as of strategies for a potential future multiplication of the applied technologies. The individual level was mainly approached within the scope of the practical and theoretical training for the operating personnel, which focused on the qualification of the staff by promoting knowledge, understanding and personal skills leading to a high commitment and a step-wise take-over of O\&M-related responsibilities.

\section{System evaluation based on operating experiences}

\section{Manual vs. full automated operation}

As described in "Machine selection" the plant's operation is oriented towards the storage level, which has to be kept within a permissible range. This goal is accomplished through a proper regulation of the water supply system and of the flood relief system in case of exceeding the plant's design discharge.

Initially a SPS-based control system was implemented to operate the plant fully automated (Walcher et al. 2009). The operating power for this control system should be provided by a sixth, smaller module, consisting of PAT and synchronous generator. However, as experience showed, due to the "black box" character of this automation events of minor malfunctions lead to considerable uncertainties of the operational personnel, partially related to downtimes of the plant for weeks. Therefore, according to the iterative implementation process described in "Elaboration of design parameters" the first main adaption measure accomplished by KIT was to switch over to manual operation supported by a comprehensive monitoring and warning system which comprises the following features:

1. Continuous monitoring of upstream and downstream water level, amount of seepage water (see "Assessment of the injection measures") and supply discharge

2. Real-time display of the monitored data on a central panel (decision support for the operating personnel regarding re-setting of the plant)

3. Alarm functions (triggering sirens and lamps) in case of exceeding previously set limiting values for the monitored parameters

4. Emergency stop function for immediate shut down the plant in case of need

5. Data storage on integrated devices for later analysis of the plant's performance

6. Autonomous operation of the monitoring system through photovoltaic energy supply.

Depending on the respective discharge variability, the changeover to manual operation requires in average during the dry season $1-2$, during the rainy season up to $4-5$ daily inspection rounds to the platform for re-setting of modules and/or controlling valves.

Generally, the crucial advantage of manual operation is the comprehensive collection of experiences by the operating personnel, whereby exceptional situations (e.g., events of high discharge, malfunctions, etc.) can be handled more easily in an appropriate way. Due to low local labor costs the plant can easily be monitored $24 / 7$ with minor additional costs compared to full automated operation. 


\section{Initial operational phase}

In parallel to the technical optimization another focus of the continuous works was set on the consolidation of the capacity development. Here comprehensive trainings were carried out applying adapted training materials, which were developed especially for this purpose. The training was carried out for the Indonesian operating team through staff members of KIT (see Fig. 16) whereby all operation and maintenance $(\mathrm{O} \& M)$ related tasks were explained and trained repeatedly. In this context operation procedures were introduced by KIT in consultation with the operating authority, which are valid independently from the chosen defined storage level but crucial to the personnel's and the plant's safety. The training material comprises bilingual (English, Bahasa Indonesia) and O\&M-related manuals, handouts and posters which are adapted to the educational background of the operating personnel. According to objectives of participatory approaches, these documents were iteratively reworked and updated in close cooperation with the Indonesian operating team.

Nevertheless, due to the plant's innovative character, there were no operating experiences at the beginning. Hence, it was agreed both by German and Indonesian side that the operation should initially be accomplished at a low normal storage level. With increasing experience, the permitted operating range was successively raised. Reasons for this procedure were the required investigation of the plant's technical condition after each increase of the defined storage level and to give the operating personnel time to get used to the plant's operation both during regular and extraordinary conditions (i.e., events of flood discharge during the rainy season). Therefore, the normal storage level was increased from 12 to $14 \mathrm{~m}$ (status October 2015) since the plant's start-up in July 2011 with the option of further increase. During the initial operating phase a continuous accompaniment of the plant's operation by KIT staff was conducted to support the operators in case of any occurring uncertainty. With increasing experiences a stepwise assignment of responsibility to the Indonesian operational team and the simultaneous reduction of the support by the German project partners were accomplished. This approach aimed for a high self-reliance of the operators so in case of any deviation from regular operation the staff will be capable to act appropriately.

\section{Assessment of the injection measures}

Due to the underground location Bribin's water storage is entirely surrounded by karst rock formations, which are applied with a hydrostatic pressure while damming up the river for the plant's operation. In consequence of the cave walls' low porosity only a minor infiltration of the river's discharge into the karst rock occurs. Considering these geological characteristics a long-term preservation of the storage level is assumed to be feasible, which can be proved for now by the monitoring data recorded via the plant's control system. However, the critical zone is the barrage surrounding rock mass, since in this area the maximum pressure gradient is applied both during regular operation as well as during exceptional situations like flood events. The related pressure load triggers seepage flows inside the rock, which might eventually result in hydraulic breakthroughs.

To successively increase the tightness of the barragesurrounding karst rock between 2009 and 2013 three grouting measures were carried out radial to the barrage and to a drilling depth of $15 \mathrm{~m}$ (Breiner et al. 2011). Hereby washout processes were meant to be prevented by hindering the water from flowing through the surrounding rock. The first measure was the general startup to implement the injection curtain. The second and third measures were of minor extent to locally reduce the occurring seepage water. In addition to the single layer grouting curtain a double layer drainage system was implemented to avoid an increase of the water pressure inside the hanging wall resp. cave roof above the machinery platform. Through this drainage system, the residual seepage flow is drained through boreholes dedicated to this purpose.

In principal, the definition of the injection curtain to a drilling depth of $15 \mathrm{~m}$ was decided accordingly to the plant's design storage level. While exceeding this level, a distinct increase of the amount of seepage water occurs. This correlation directly influences the plant's operational mode (see "Manual vs. full automated operation" and "Evaluation of the plant's utilization") since storage levels beyond $15 \mathrm{~m}$ shall be avoided as far as possible. Both, the plant's technical adaption (e.g., implementation of an adapted control system for manual operation) as well as the training of the operating personnel focused on this safety related issue.

Figure 17 shows exemplarily the correlation between storage level and the occurrence of seepage water. Here, the exceedance of a storage level of $15 \mathrm{~m}$ leads to a distinct and delayed but (up to now) reversible increase of seepage water. This reversibility can be seen while decreasing the storage level to the permitted range, which triggers a delayed reduction of the seepage water to the pre-incident level. This re-decrease indicates that no sediments are flushed out by seepage flow as well as that existing karst cavities are not substantially widened by dissolution processes (Kudella et al. 2015).

Overall, a long-term limitation of the amount of seepage water below $10 \mathrm{l} / \mathrm{min}$ during regular operation (storage level below $15 \mathrm{~m}$ ) was accomplished through the injection measures. With each injection campaign the mean amount of seepage water was lowered, though the gain of each 

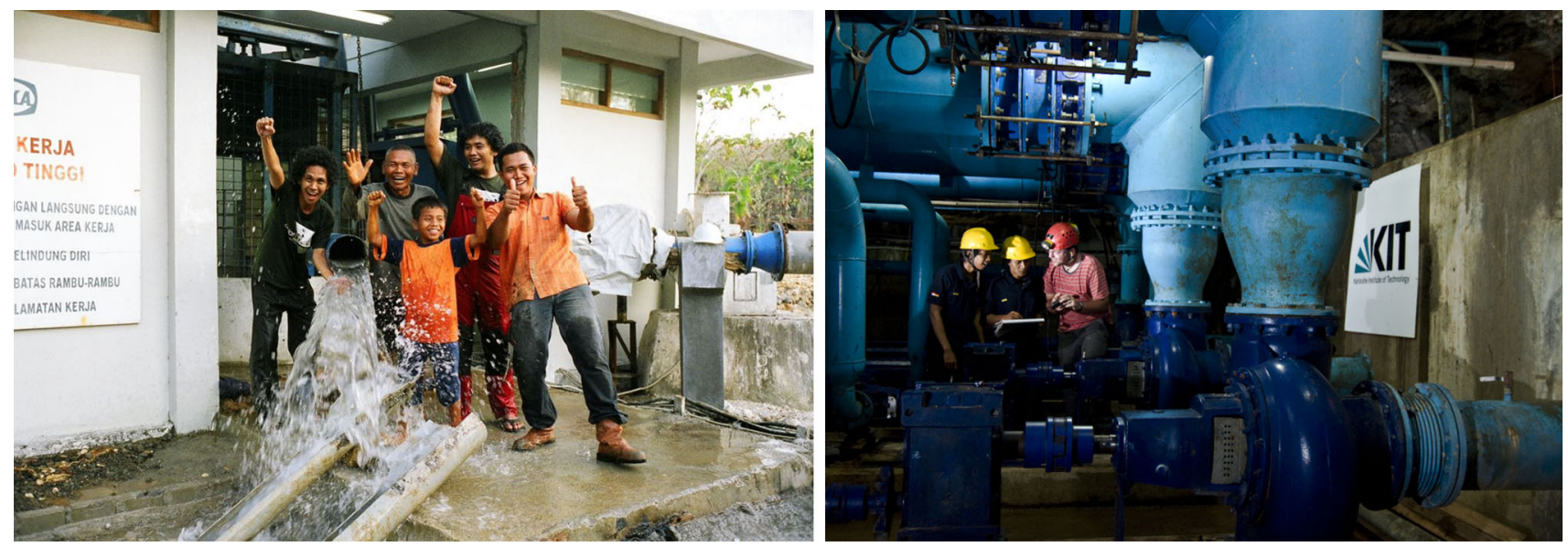

Fig. 16 Accomplishment of the first operational test (left) and know-how transfer during the initial operational phase (right)



Fig. 17 Illustration of the correlation between storage level and seepage water: (1) widely constant storage levels lead to steady and acceptable low seepage, (2) an decrease (increase) of the storage level causes a successive deceeding (incline) of seepage

campaign decreased. Against this background and based on a re-evaluation of all data recorded since the plant's commissioning the current status (October 2015) does not require any near-term injection measures. This recommendation also considers an increasing risk of deterioration (through injection pressures and changed hydraulic regimes) due to consecutive campaigns within a short period of time. For being able to decide about the necessity of future injection campaigns, the continuation of seepage monitoring applying the control system is inevitable in order to detect any changes earliest possible (Kudella et al. 2015).

\section{Assessment of the supply system's efficiency}

Prior to the on-site installation, the partial efficiencies of all machines (PAT and feed pump) and components (gearbox and couplings) had been evaluated on the test field of the
German industry partner KSB AG. This assessment was associated by a mechanical modification of the PAT's standard design increasing its as well as the plant's overall efficiency (Oberle et al. 2009). After commissioning of the plant a continuous assessment of the supply system's machinery was carried out by KIT in cooperation with KSB AG and the Indonesian project partners. This evaluation focused on the viable supply discharge, which is depending on the number of driven modules (resp. the available river discharge) as well as on the applied storage level. Figure 18 shows (1) the supply system's design values, (2) the results of a measurement campaign conducted by KIT in 2011 as well as (3) the continuously recorded data related to the plant's operation.

Especially referring to the 2014 monitoring data it can be shown that the water supply capacity of the entire plant did not decrease since the plant's commissioning. Furthermore, Fig. 18 shows that the values measured during the 2011-campaign as well as the continuously recorded data meet the expectations on the plant's water supply capacity with a varying number of operated modules.

With an increasing number of modules in operation, a predominantly positive and also increasing deviation between design and reality was observed. The comparison of design values and measured data leads to the conclusion, that the occurring flow-related energetic losses are lower than expected. In this regard it has to be stated, that the plant's design was chosen conservatively (loss coefficients were defined at the upper end of the respective scale), since the implementation of the entire water supply system was afflicted with various uncertainties (e.g., vague local production quality for pipes and fittings). Overvalued friction coefficients, however, lead to inflated calculated energetic losses, which even aggravates with increasing discharge due to the quadratic dependence between energetic losses and flow velocity. 

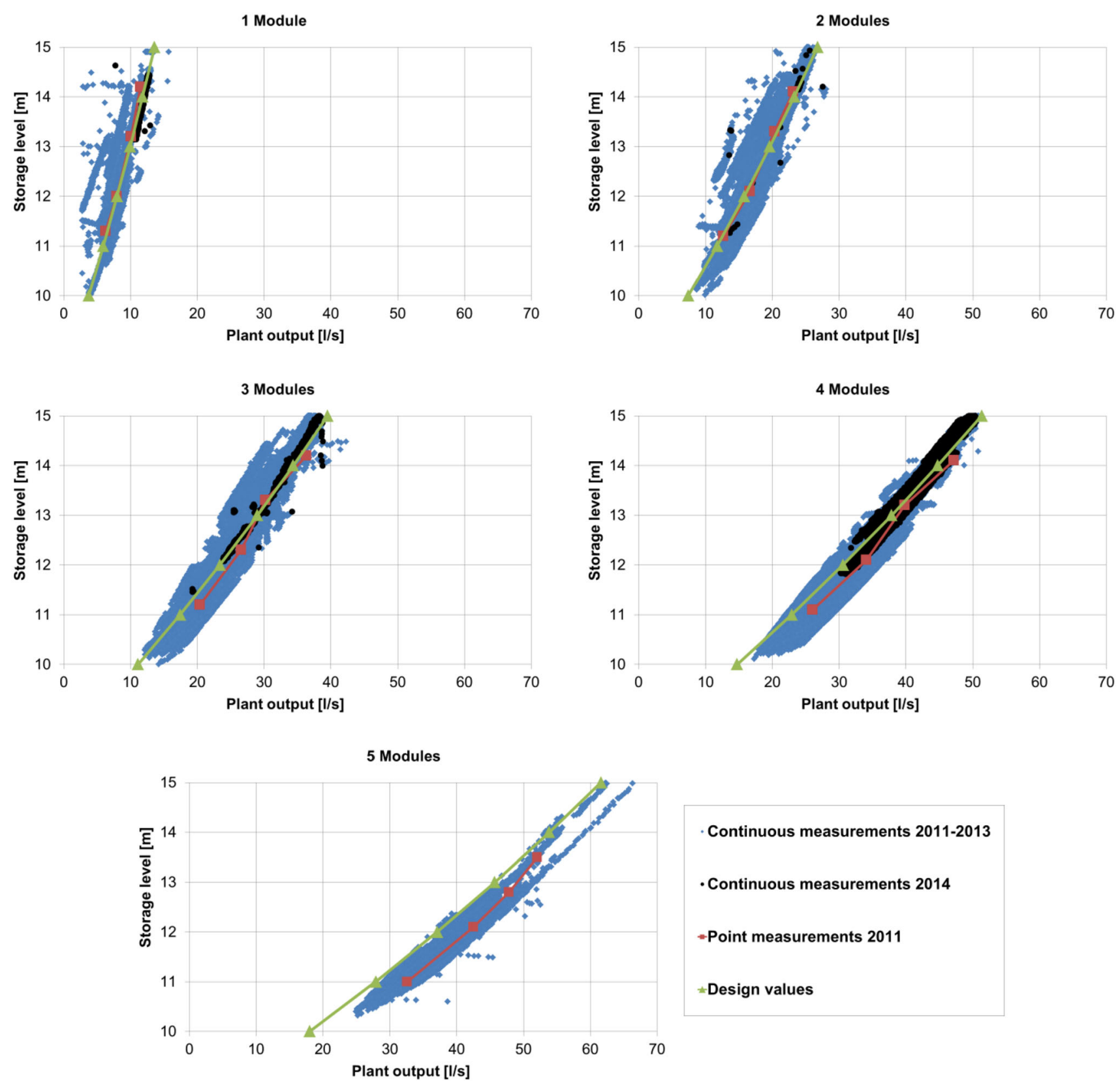

Fig. 18 Output performance depending on the number of driven modules and the storage level; data from continuous measurements by the control system from $07 / 2011$ to $12 / 2013$, continuous

Furthermore, an increasing scattering of the measured values was observed with decreasing number of operated modules. Hereto, additional measurements accomplished during the 2011 campaign lead to the conclusion that the machines' single efficiencies slightly differ (due to general production-related fluctuation) causing a deviation of the modules' supply discharge at a respective storage level. In this regard, the international standard DIN EN ISO 9906-2013-03 allows certain deviations (depending on the measurements by the control system between 01/2014 and 06/2014, measurement campaign by KIT in autumn 2011 and calculated design values

classification resp. quality level of the machine) of the supply discharge and the power consumption, leading to a permitted variation of a pump's single efficiency from the nominal value by $\pm 6 \%$. Against this background a varying plant output of different module combinations at a certain storage level can be implied. This conclusion is supported by the fact that with increasing number of operated modules the quantity of module combinations decreases and thus the scattering declines. 


\section{Evaluation of the plant's utilization}

Besides the design capacity of the machinery the natural discharge availability resp. its variability is the major influencing factor on the viable supply discharge. In this context Fig. 19 shows the monthly averaged discharge of Bribin River, which mainly refers to the continuously measured operating parameters recorded by the plant's monitoring system between July 2011 and June 2014.

To operate the plant at its design storage level of $15 \mathrm{~m}$ with full capacity ( 5 modules in operation), the related water demand (design discharge) sums up to $2 \mathrm{~m}^{3} / \mathrm{s}$. Considering the standard deviations of the discharge values shown in Fig. 19, this design discharge is exceeded in at least 7 months per year. The minimum mean monthly discharge of approx. $1.3 \mathrm{~m}^{3} / \mathrm{s}$ was measured in October which matches the end of dry season. The maximum mean monthly value of approx. $6.3 \mathrm{~m}^{3} / \mathrm{s}$ was observed in January which is timed in the mid of rainy season. In addition, the analysis of all measurement data showed that the observed minimum was approx. $0.6 \mathrm{~m}^{3} / \mathrm{s}$, the maximum discharge approx. $12 \mathrm{~m}^{3} / \mathrm{s}$.

The values shown in Fig. 19 also illustrate a high discharge variability at the beginning of the rainy season (December) leading to a challenging plant operation (requirement of frequent readjustments of the plant's settings). This can be explained by the occurrence of single heavy rainfall events and the commencement of the karst rock's refilling leading to a comparatively low base discharge associated with high peak values. Subsequently this discharge variability decreases until reaching its minimum in October at the end of the dry season. This point in time is commonly associated with an almost entirely drained karst rock leading to low overall discharge values.



Fig. 19 Bribin River's discharge: Mean monthly values as block diagram (assessment of continuously recorded data between 07/2011 and 06/2014), standard deviation as dot combined with an upper and lower limit, supply system's design discharge as dashed line
The observed water yield serves further on as basis for the calculation of the plant's supply potential, associated by consideration of the permitted operating range and the characteristic curves of the machinery. Table 1 shows the potential utilization values based on the design storage level of $15 \mathrm{~m}$, which can be approached by the plant's actual performance. According to these findings a plant utilization of at least $80 \%$ (equals a continuous operation of 4 modules) is viable in 9 months a year. During rainy season, the continuous operation at full capacity is possible in 5 consecutive months. Referring to Fig. 19 the minimum discharge was observed in October, which is equivalent to the end of the dry season and characterized by severe water shortage in the region of Gunung Sewu. However, Table 1 shows that the effective utilization of this minimum discharge still allows the operation of more than three modules at a time (continuous operation of three modules, intermittent operation of a fourth module) supplying $40-451 / s$ to the elevated storage.

During continuous operation of the plant an increase of the all-season mean supply discharge was accomplished among others through (1) comprehensive and repeated training of the local staff (see "General implementation process" and "Manual vs. full automated operation"), (2) reduction of downtimes, e.g., by extension of the flood relief system's discharge capacity (see "Discharge monitoring") and (3) through a step-by-step increment of the permissible operating range (see "Initial operational phase"). With regard to the plant's $24 / 7$ operation, the annual water supply to the elevated storage was thus increased from $623 \times 10^{3} \mathrm{~m}^{3}$ (1st operating year) to $744 \times 10^{3} \mathrm{~m}^{3}$ (3rd operating year). In the future, the viable mean supply discharge can further approach the theoretical value through continuous employment of experienced operating personnel and proper maintenance of the supply system. Under these preconditions and based on the gained operating experience an increase of the mean annual supply discharge to $42 \mathrm{l} / \mathrm{s}$ is expected as viable during the upcoming years (this equals $80 \%$ of the theoretical mean annual supply discharge of $52 \mathrm{l} / \mathrm{s}$ with reference to the design storage level of $15 \mathrm{~m}$ ).

\section{Economical assessment and comparison to alternative supply concepts}

Besides the technical and operational analyses, the plant's continuous performance was evaluated also from economic point of view. To being able to classify the results of Bribin's economic analysis, further calculations were carried out considering conventional supply facilities (pumping systems driven by power grid or diesel generators) at the same location. Here, the costs related to operation and maintenance for each alternative were quantified as a 
Table 1 Potential plant utilization and supply discharge as function of the number of operated modules (assessment of continuously recorded data between 07/2011 and 06/2014)

\begin{tabular}{llllllllllllll}
\hline No. of operated modules (-) & & & & & & & 2 & 3 & 4 & 5 \\
\hline Mean supply discharge (1/s) at design storage level of $15 \mathrm{~m}$ & & & & & 13.6 & 26.8 & 39.5 & 51.3 & 61.6 \\
\hline Month & Jan & Feb & Mar & Apr & May & Jun & Jul & Aug & Sep & Oct & Nov & Dec \\
\hline No. of operable modules (-) & 5 & 5 & 5 & 5 & 5 & 4.8 & 4.8 & 4.2 & 3.9 & 3.4 & 3.4 & 4.2 \\
Theoretical supply discharge (1/s) & 61.6 & 61.6 & 61.6 & 61.6 & 61.6 & 59.5 & 59.5 & 53.4 & 50.1 & 44.2 & 44.2 & 53.4 \\
Viable supply discharge (1/s) & 49.3 & 49.3 & 49.3 & 49.3 & 49.3 & 47.6 & 47.6 & 42.7 & 40.1 & 35.4 & 35.4 & 42.7 \\
\hline
\end{tabular}

function of the supply discharge (investigation range up to the theoretical mean supply discharge of $52 \mathrm{l} / \mathrm{s}$ ).

For conventional supply facilities the profitability is distinctly depending on the mean annual supply discharge, wherefore a sensitivity analysis was accomplished for each system variant. According to the gained results, a profitable operation based on a diesel generator driven supply systems is not feasible at the Bribin site due to the considerable costs for diesel fuel. Exemplary calculations based on the current price for diesel fuel (status October 2015) and on the above stated viable mean supply discharge of $42 \mathrm{l} / \mathrm{s}$ showed that the annual costs related to diesel fuel sum up to approx. $280.000 €$. Even though the investment costs would be distinctly lower compared to the "Bribin system", the profitability was not given. As a consequence this supply option was neglected for further analyses.

By contrast electric-driven systems are able to compete economically with the hydropower-driven system of Bribin. Here, investment costs distinctly lower than the ones related to the "Bribin system" are associated with costs for electric energy, which sum up to approx. $90.000 €($ exemplary calculations based on the electricity rate of October 2015 and on a mean annual supply rate of 42 1/s). The profitability of this alternative, however, firstly depends on the connectability of the plant to an existing power grid, which would not be the case for the Bribin site (so actually additional costs would occur). Secondly the profitability depends on the price trend for electricity, since this source of energy is currently significantly subsidized by the Indonesian government. Indeed, referring to today's electricity rate the price per kilowatt hour is assumed to increase by approx. $25 \%$ until 2019, since starting at this point in time the Indonesian Ministry of Energy and Mineral Resources (ESDM) will define the electricity rate solely market-based (IISD 2014; PLN 2014). The O\&Mrelated costs of the hydropower-driven "Bribin system", however, show hardly any sensitivity to the mean supply discharge, whereby the plant's profitability can easily and sustainably be increased.

Complementary investigations of KIT focused on the comparison of the "Bribin system" with water supply facilities utilizing volatile forms of energy, namely photovoltaic (PV) and wind energy. Even though PV systems are already used for various decentralized applications (including water pumping systems), only small-scale offgrid facilities with a capacity of less than $10 \mathrm{~kW}$ have been successfully implemented yet (status October 2015) (Schumacher Center 2012). Off-grid solutions with an installed capacity above $100 \mathrm{~kW}$ are currently in development stage and might be a suitable alternative for decentralized applications in the future (Ebaid et al. 2013; Odeh 2014). This constraint mainly refers to the high variability of the insulation as a major influencing factor on the PV system's output capacity. Accordingly, a sustainable water supply requires the integration of costly battery buffer systems and water storages to compensate temporal power supply variations. This, however, will distinctly increase the system's complexity which is disadvantageous for the application in remote areas as, e.g., experienced with Bribin's control system (see "Manual vs. full automated operation"). Based on these findings, it is assumed that currently an off-grid PV-based energy supply is no proper solution to enable a sustainable water supply with power consumption distinctly above $100 \mathrm{~kW}$.

Since the wind velocity as indicator for the generable wind energy is also a hard-to-predict parameter, the utilization of wind power stations is afflicted with similar constraints as described for photovoltaic plants. Furthermore, the technical-economic minimum velocity of $5 \mathrm{~m} / \mathrm{s}$ (Cloutier and Rowley 2011) cannot be reached at the Bribin site (NASA 2013), wherefore this source of energy is currently also not considered as a potential alternative to a hydropower drive at this location.

\section{Outlook}

The successful long-term operation of the water supply facility Bribin secures the water supply for 75,000 people and therefore contributes to a sustainable development of the region Gunung Sewu. According to the findings shown in this present paper, the implemented water supply 
concept proofed its applicability under very demanding conditions. In the future regions suffering from similar problems in terms of a lacking or deficient water supply can be addressed within the frame of multiplication projects. By applying highly adaptable technologies, which are incorporated in a decentralized approach, the implementation also in areas with poor infrastructure is enabled. As shown by the example of the hydropower-driven reference plant commonly used supply options such as conventional pumping stations and water trucks can be substituted in a sustainable way.

Based on KIT's technology and knowhow transfer related to the erection and operation of Bribin Indonesian public authorities and partners from local universities are currently working autonomously on the exploitation of a second all-season water-bearing karst cave in the region Gunung Sewu. The here planned implementation of an alternative water supply concept, which is also based on the idea of Bribin's hydropower-driven water supply system, greatly shows the acceptance of this adaptable and promising technology. Furthermore, through the capacity development measures of the IWRM network carried out on the institutional level, the Indonesian government was supported to initiate a nationwide master plan to assess and utilize the underground water potentials in karst areas of Indonesia.

In addition, a German-Vietnamese joint-R\&D-project under the aegis of KIT is currently working on further fields of application for the hydropower-driven water supply technology. This follow-up project in the Ha Giang province in North Vietnam focuses on the extension of existing high-pressure hydropower plants by a water supply system, which utilizes residual flows especially during the dry season. This innovative approach will help to sustainably supply the people living in this distinctly remote area with fresh water. Additionally the KIT and KSB AG develop concepts for an encapsulated and low-maintenance water supply system to be applied under extreme natural boundary conditions. Both approaches can later be adapted to various karst and non-karst, surface and subsurface locations to locally improve the water supply in an ecologic and economic sustainable way.

Acknowledgments The authors would like to thank the German Federal Ministry of Education and Research (BMBF) as well as all related industry partners for continuously supporting the $R \& D$ activities.

Open Access This article is distributed under the terms of the Creative Commons Attribution 4.0 International License (http:// creativecommons.org/licenses/by/4.0/), which permits unrestricted use, distribution, and reproduction in any medium, provided you give appropriate credit to the original author(s) and the source, provide a link to the Creative Commons license, and indicate if changes were made.

\section{References}

Alaerts G (2009) Knowledge and capacity development (KCD) as tool for institutional strengthening and change. In: Alaerts G, Dickinson NL (eds) Water for changing world-developing local knowledge and capacity. Taylor and Francis, London, pp 5-26

Breiner R, Müller HS (2015) The role of material engineering within the concept of an integrated water resources management (working title). Submitted to Applied Water Sciences

Breiner R, Bohner E, Fenchel M, Müller HS, Mutschler T, Triantafyllidis T (2011) Grouting of an Underground Concrete Barrage in Karst Limestone. In: Haryono E. et al. (ed) Asian trans-disciplinary karst conference. Faculty of Geography, Gadjah Mada University, Yogyakarta, pp. 181-190

Brunsch A, Adji TN, Stoffel D, Ikhwan M, Oberle P, Nestmann F (2011) Hydrological assessment of a karst area in Southern Java with respect to climate phenomena. In: Haryono E. et al. (ed) Asian trans-disciplinary karst conference. Faculty of Geography, Gadjah Mada University, Yogyakarta, pp. 55-68

Cloutier M, Rowley P (2011) The feasibility of renewable energy sources for pumping clean water in sub-saharan Africa: a case study for Central Nigeria. Renew Energy 36(8):2220-2226

Dittmann A, Fach S, Fuchs S, Hossu M, Nestmann F, Oberle P (2011) Aspekte des Wasserressourcen-Managements in Karstgebieten am Beispiel der Region Gunung Kidul auf Java, Indonesien. Hydrol Water Resour Manag 55(2):57-67

Ebaid MSY, Qandil H, Hammad M (2013) A unified approach for designing a photovoltaic solar system for the underground water pumping well-34 at Disi aquifer. Energy Conserv Manag 75:780-795

Ford D, Williams P (2007) Karst hydrology and geomorphology. Wiley, Chichester, p 563

Goldscheider N, Drew D (2007) Methods in karst hydrogeology. International Constributions to hydrogeology. Taylor \& Francis, London

IISD International Institute for Sustainable Development (2014) Indonesia energy subsidy review. Issues 1, vol. 1, March 2014

KEMENNEG PDT State Ministry for Development of Disadvantaged Regions (2005) Decree of the Minister 001/KEP/M-PDT/I/2005. National Development Strategic for Disadvantaged Regions

Kudella P, Loges I, Mutschler T, Eiche E, Ruppert J, Neumann T (2015) Bypassing and tightening of the HPP Bribin water retention system in Permeable Karst (working title). Submitted to Applied Water Sciences

Lux T (2004) Sozioökonomische Auswirkungen einer verbesserten Wasserversorgung auf die lokale Bevölkerung in Gunung Sewu, Indonesien. Master Thesis Justus-Liebig-Universität Gießen, Institut für Geographie

MacDonald and Partners (1984) Greater Yogyakarta ground water resources study. Vol. 03: vol. 03: Groundwater. Project report

Milanovic P (2002) The environmental impacts of human activities and engineering construction in karst regions. Episodes 25(1):13-21

NASA (2013) Windgeschwindigkeitsangaben für den Standort Bribin (1983 bis 2005). https://eosweb.larc.nasa.gov/cgi-bin/sse/grid. cgi?email=skip@larc.nasa.gov. Accessed 30 Oct 2013

Nestmann F, Oberle P, Ikhwan M, Lux T, Scholz U (2009) Bewirtschaftung unterirdischer Fließgewässer in Karstgebieten-Pilotstudie auf Java, Indonesien. In: WasserWirtschaft 99, Heft 7-8

Nestmann F, Oberle P, Ikhwan M, Klingel P (2010) Adaptive water resources management under extreme climatic and hydrogeological conditions-interdisciplinary research activities in karst 
regions of South East Asia. IWRM-Karlsruhe 2010, November 2010, S. 300-307

Nestmann F, Oberle P, Ikhwan M, Stoffel D (2012) Experiences concerning the implementation of innovative technologies and management strategies in emerging countries: example IWRM Indonesia. Proceedings of the IWRM Karlsruhe 2012, Karlsruhe, November 21-22, 2012, pp. 41-53

Nestmann F, Oberle P, Ikhwan M, Stoffel D (2015) Transfer of adapted water supply technologies through a demonstration and teaching facility (working title). Submitted to Applied Water Sciences

Neumann T, Benner Z, Stuben D, Bahri S, Jaya M (2009) Geowissenschaftliche Bewertung von Karsthöhlen für die Wasserbewirtschaftung in Gunung Sewu. WasserWirtschaft 99, Heft 7-8

Nguyen LV, Nguyen NK, Hoang HV, Tran TQ, Vu NT (2013) Characteristics of groundwater in karstic region in northeastern Vietnam. Environ Earth Sci 70:501-510

Nibbering JW (1991) Crisis and resilience in upland use in Java. In: Hardjono J (ed) Indonesia: resources, ecology and environment. Oxford, New York pp. 104-132

Oberle P (2011) Hydrologische Studien in der Karst Region Gunung Kidul, Indonesien, unter Berücksichtigung von Klimaphänomenen. Hydrobrief, Fachgemeinschaft für Hydrologische Wissenschaften (FgHW), December 2011

Oberle P, Nestmann F (2006) Bau unterirdischer Wasserspeicher in Karstgebieten auf Java. Wasserbausymposium Graz 2006: Stauhaltungen und Speicher von der Tradition zur Moderne, TU Graz, Schriftenreihe zur Wasserwirtschaft, Bd. 46/1, pp. 406-421

Oberle P, Ikhwan M, Nestmann F, Fritz J, Ravisundar T (2009) Angepasste Wasserfördertechnologie unter Einsatz von Pumpen im Turbinenbetrieb. WasserWirtschaft 99, Heft 7-8

Odeh I (2014) Production Economic feasibility of large scale PV water pumping applications utilizing real field data for a case study in Jordan. Int J Renew Energy Develop 3(2):107-117
PLN, state-owned electricity company (2014) Towards economic price in electricity. http://www.pln.co.id/blog/menujukeekonomian-tarif-listrik-di-indonesia. Accessed 23 Mar 2015

Scholz U, Unger B, Lux T (2004) Sozioökonomische Analyse potenzieller Wassernutzer in Mitteljava, Indonesien. BMBF Project Report, Institute for Geography, Justus-Liebig-University Giessen

Schumacher Centre (2012) Technical brief: solar (photovoltaic) water pumping. Practical Action, UK

Singh P (2005) Optimization of internal hydraulics and of system design for pumps as turbines with field implementation and evaluation. Ph.D. Dissertation, Institute for Water and River Basin Management, Karlsruhe Institute for Technology (KIT)

UNESCO/Division of Water Sciences (2003) Wasser für Menschen, Wasser für Leben. Weltwasserentwicklungsbericht der Vereinten Nationen. UNO-Verlag GmbH

UNICEF and WHO (2012) Progress on drinking water and sanitation, 2012 Update, New York. ISBN 972-924-1503297

Van Hofwegen P (2004) Capacity-building for water and irrigation sector management with application in Indonesia. FAO Water Reports, Rome, p. 26

Walcher H, Lösche M, Oberle P (2009) Steuer- und Regelungskonzept für den modularen Betrieb der unterirdischen Wasserförderanlage Bribin. In: WasserWirtschaft 99, Heft 7-8

Waltham AC, Smart PL, Friedrich H, Atkinson TC (1985) Exploration of caves for rural water supplies in the Gunung Sewu Karst, Java. Annals de la Societe Geologique de Belgique, T. 108:27-31

Wang SJ, Liu QM, Zhang DF (2004) Karst rocky desertification in southwestern China: geomorphology, landuse, impact and rehabilitation. Land Degrad Dev 15:115-121

Williams P, Ford D (2006) Global distribution of carbonate rocks. Zeitschrift für Geomorphologie Suppl Band 147:S1-S2 